\title{
Ornithinimicrobium humiphilum gen. nov., sp. nov., a novel soil actinomycete with L-ornithine in the peptidoglycan
}

\author{
Ingrid Groth, ${ }^{1}$ Peter Schumann, ${ }^{2}$ Norbert Weiss, ${ }^{2}$ Barbara Schuetze, ${ }^{1}$ \\ Kurt Augsten ${ }^{3}$ and Erko Stackebrandt ${ }^{2}$
}

\footnotetext{
1 Hans-Knöll-Institut für Naturstoff-Forschung e.V., D-07745 Jena, Germany

2 DSMZ-Deutsche

Sammlung von

Mikroorganismen und

Zellkulturen $\mathrm{GmbH}$

D-38124 Braunschweig,

Germany

3 Institut für Molekulare Biotechnologie e.V., D-07745 Jena, Germany
}

Author for correspondence: Ingrid Groth. Tel: +4936416566 66. Fax: +4936416566 60. e-mail: igroth@pmail.hki-jena.de

\begin{abstract}
A Gram-positive bacterium originating from garden soil was taxonomically studied. Cells are non-motile, non-sporulating, irregular rods and cocci. The cell wall peptidoglycan contains L-ornithine as diagnostic diamino acid and an interpeptide bridge consisting of L-Orn $\leftarrow L$-Ala $\leftarrow$ Gly $\leftarrow D$-Asp. The major menaquinone is $\mathrm{MK}-8\left(\mathrm{H}_{4}\right)$. 13-Methyl tetradecanoic acid and 14-methyl pentadecanoic acid are the predominant fatty acids. The polar lipids are phosphatidylinositol, phosphatidylglycerol, diphosphatidylglycerol, three unknown glycolipids and three unknown phospholipids. Mycolic acids are absent. The DNA G+C composition is $70 \mathrm{~mol} \%$. The acyl type of the glycan chain of peptidoglycan is acetyl. Glucose is the dominating whole cell sugar; arabinose, rhamnose and xylose are present in traces. Results of 16S rDNA sequence comparisons revealed that strain HKI $0124^{\top}$ represents a novel lineage within the suborder Micrococcineae of the order Actinomycetales adjacent to the recently described genus Ornithinicoccus. On the basis of the clearly pronounced morphological, physiological, chemotaxonomic and phylogenetic differences between strain HKI $0124^{\top}$ and all members of the suborder Micrococcineae, it is proposed to assign strain HKI $0124^{\top}$ to a new genus and species, Ornithinimicrobium humiphilum gen. nov., sp. nov. The type and only strain is HKI 0124 ${ }^{\top}$ (= DSM $12362^{\top}=$ CIP $^{106634} 4^{\top}$ ).
\end{abstract}

Keywords: Ornithinimicrobium humiphilum gen. nov., sp. nov., L-ornithine-containing actinomycete

\section{INTRODUCTION}

Actinomycetes that contain ornithine as diagnostic diamino acid in their peptidoglycan are phylogenetically assigned to the families Cellulomonadaceae (Cellulomonas, Rarobacter) and Microbacteriaceae (Microbacterium, Curtobacterium) within the suborder Micrococcineae (Stackebrandt et al., 1997). The recently described genus Ornithinicoccus, however, still awaits a decision on a family affiliation (Groth et al., 1999). The type strain of Ornithinicoccus hortensis possesses only 12 of the 17 family signature nucleotides described for the family Intrasporangiaceae (Stackebrandt et al., 1997), the members of which are

The EMBL accession number for the 16S rDNA sequence of Ornithinimicrobium humiphilum strain $\mathrm{HKI} 0124^{\mathrm{T}}$ is $\mathrm{AJ} 277650$. the closest phylogenetic neighbours of the genus Ornithinicoccus.

In this paper, characteristics of another isolate originating from the same soil sample as Ornithinicoccus hortensis are described. Despite the common occurrence of L-ornithine in the cell wall peptidoglycan and the predominant menaquinone $\mathrm{MK}-8\left(\mathrm{H}_{4}\right)$ in both strains, remarkable differences in morphological, physiological and further chemotaxonomic features were found. Phylogenetically, strain HKI $0124^{\mathrm{T}}$ forms a novel lineage within the suborder Micrococcineae adjacent to Ornithinicoccus hortensis but clearly distinct from this genus and from all other members of the order Actinomycetales.

Results presented in this study have revealed that strain HKI $0124^{\mathrm{T}}$ should be placed in a new genus and species, for which the name Ornithinimicrobium 


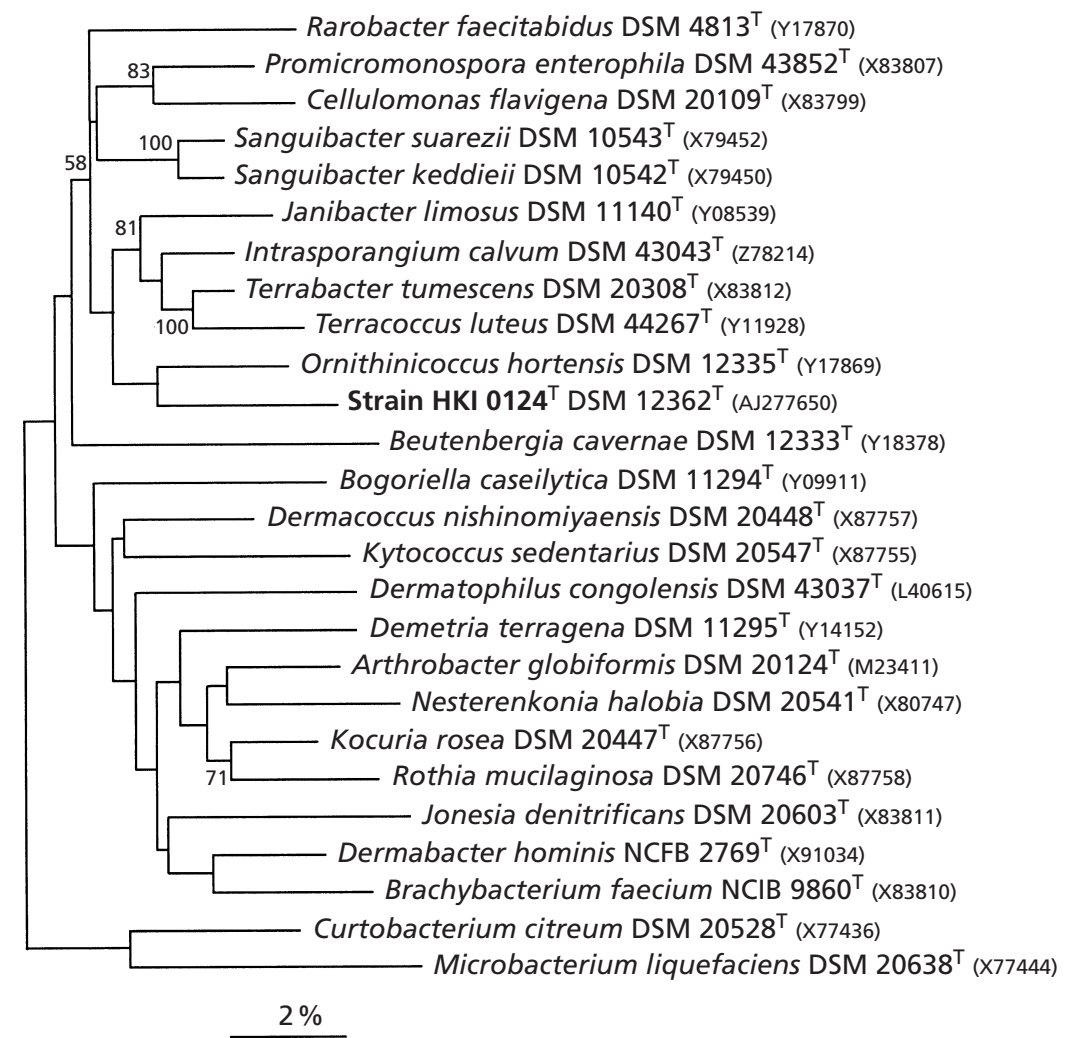

Fig. 1. 16S rDNA sequence-based phylogenetic dendrogram constructed from evolutionary distances (De Soete, 1983) showing the phylogenetic position of strain HKI $0124^{\top}$ next to members of the family Intrasporangiaceae and other families of the suborder Micrococcineae (Stackebrandt et al., 1997). Numbers at branching points refer to bootstrap values (500 trees resampled); only values above $70 \%$ are indicated. Scale bar, two inferred nucleotide substitutions per 100 nucleotides. humiphilum is proposed. The type strain of Ornithinimicrobium humiphilum is HKI $0124^{\mathrm{T}}$ (= DSM $12362^{\mathrm{T}}=$ CIP $\left.106634^{\mathrm{T}}\right)$.

\section{METHODS}

Bacterial strain and cultivation conditions. Strain HKI $0124^{\mathrm{T}}$ was isolated from a sample of garden soil (Giessen, Germany). The isolation procedure and laboratory cultivation have been described by Groth et al. (1999).

Morphological and physiological characteristics. Microscopic studies including colony and cell morphology, motility, measurement of cell dimensions and preparation of cells for scanning electron microscopy were performed as described by Groth et al. (1997, 1999). Gram staining, acidfast staining and growth dependence on different incubation temperatures, increasing concentrations of $\mathrm{NaCl}$ and oxygen supply, as well as the utilization of various organic compounds and selected enzyme activities have also been described previously (Groth et al., 1997). The susceptibility to antibiotics was tested by placement of antibiotic discs (Oxoid) on $\mathrm{R}$ agar plates seeded with a suspension of strain HKI 0124 (Groth et al., 1997).

Cell wall analysis. Purified cell wall preparations were obtained by the method of Schleifer \& Kandler (1972). The amino acids and peptides in cell wall hydrolysates were analysed by two-dimensional ascending TLC on cellulose plates using the solvent systems of Schleifer \& Kandler (1972). The amino-terminal amino acid of the interpeptide bridge was determined by dinitrophenylation as described by Schleifer (1985). Whole-cell sugars were determined as alditol acetates by GC as described by Groth et al. (1996). The molar ratios of amino acids were determined by GC and
GC-MS of $N$-heptafluorobutyryl amino acid isobutyl esters (MacKenzie, 1987). Analysis of enantiomers of cell wall amino acids was performed by GC of $N$-pentafluoropropionyl amino acid isopropyl esters (Frank et al., 1980) on an L-Chirasil-Val column $(25 \mathrm{~m} \times 0.25 \mathrm{~mm}$ i.d.; MachereyNagel) using helium as carrier gas at a linear velocity of $200 \mathrm{~mm} \mathrm{~s}^{-1}$ and at a temperature programmed from 80 to $190{ }^{\circ} \mathrm{C}$ at a rate of $2{ }^{\circ} \mathrm{C} \mathrm{min}{ }^{-1}$. Instruments used for $\mathrm{GC}$ and GC-MS were as specified previously (Groth et al., 1996). The glycolate content of bacterial cell walls was determined by the colorimetric method of Uchida \& Aida (1984).

Lipid analysis. Cellular fatty acid methyl esters obtained from cells grown in Bacto tryptic soy broth at $28^{\circ} \mathrm{C}$ by the method of Stead et al. (1992) were separated by GC (Groth et al., 1996) and identified as described previously (Schumann et al., 1997). Menaquinones were extracted as described by Collins et al. (1977) and were analysed by HPLC (Groth et al., 1997). Polar lipids extracted by the method of Minnikin et al. (1979) were identified by twodimensional TLC and spraying with specific reagents (Collins \& Jones, 1980). The absence of mycolic acids was demonstrated by TLC (Minnikin et al., 1975).

DNA base composition. DNA was isolated and its $\mathrm{G}+\mathrm{C}$ content was determined by HPLC of deoxyribonucleosides as described by Groth et al. (1996).

$16 S$ rDNA sequence determination and phylogenetic analysis. Preparation of genomic DNA from strain HKI 0124 was done as described previously (Rainey et al., 1996). Sequences were aligned manually with previously published sequences. These were stored in the DSMZ database consisting of several thousand $16 \mathrm{~S}$ rDNA sequence entries, including those from the Ribosomal Database Project (Maidak et al., 1997) and EMBL. Similarity values were 
transformed into phylogenetic distance values that compensate for multiple substitutions at any given site in the sequence (Jukes \& Cantor, 1969). The algorithm of De Soete (Maidak et al., 1997) and the neighbour-joining method contained in the PHYLIP package (Felsenstein, 1993) were used in the construction of phylogenetic dendrograms. Bootstrap values were determined according to Felsenstein (1993). All analyses were done on a SUN SparcII workstation.

Nucleotide accession numbers. The accession numbers of the type strains used in the phylogenetic analysis are shown in Fig. 1.

\section{RESULTS AND DISCUSSION}

\section{Phylogenetic analysis}

The almost complete primary structure of $16 \mathrm{~S}$ rDNA, consisting of 1489 nucleotides $[96.4 \%$ of the Escherichia coli sequence (Brosius et al., 1978)], has been determined and compared to the type strains of species of the order Actinomycetales. The highest binary similarity values were found with members of the family Intrasporangiaceae [excepting Sanguibacter (E. Stackebrandt and P. Schumann, unpublished results; 92.2-93.7\%), Janibacter (93.2-93.9\%) and Ornithinicoccus hortensis (95.2\%)]. The latter organism has recently been described to phylogenetically branch adjacent to members of the family Intrasporangiaceae. The decision for not including Ornithinicoccus hortensis in the family Intrasporangiaceae was based on significant differences in the peptidoglycan type and the lack of five of the 17 signature nucleotides described as being specific for Intrasporangiaceae. Phylogenetic analysis applying neighbour-joining analysis and the algorithm of De Soete (1983) places strain HKI $0124^{\mathrm{T}}$ adjacent to Ornithinicoccus hortensis but the branching point is deep and not supported by high bootstrap values. Strain HKI $0124^{\mathrm{T}}$ shares with Ornithinicoccus hortensis 12 signature nucleotides specific for the family Intrasporangiaceae. However, only one out of the five signature nucleotides which differentiate Ornithinicoccus hortensis and strain HKI $0124^{\mathrm{T}}$ from members of the family Intrasporangiaceae has the same base composition in both ornithine-containing organisms.

The addition of a single new strain to the Ornithinicoccus lineage of descent and the lack of high bootstrap values have prevented designation of a new family for these two strains.

\section{Morphological and physiological characteristics}

Cells are irregular short rods and cocci, occurring singly, in pairs, short chains or clusters. Filamentous cells with swollen club-shaped ends or a tendency to primary branching and single spherical cysts were additionally observed subsequent to the isolation and later in a few cultures. Cell sizes varied depending on the culture conditions. Rods were about $1 \cdot 4-3 \cdot 2 \mu \mathrm{m}$ in length and $0.6-1 \cdot 0 \mu \mathrm{m}$ wide. The cocci had diameters

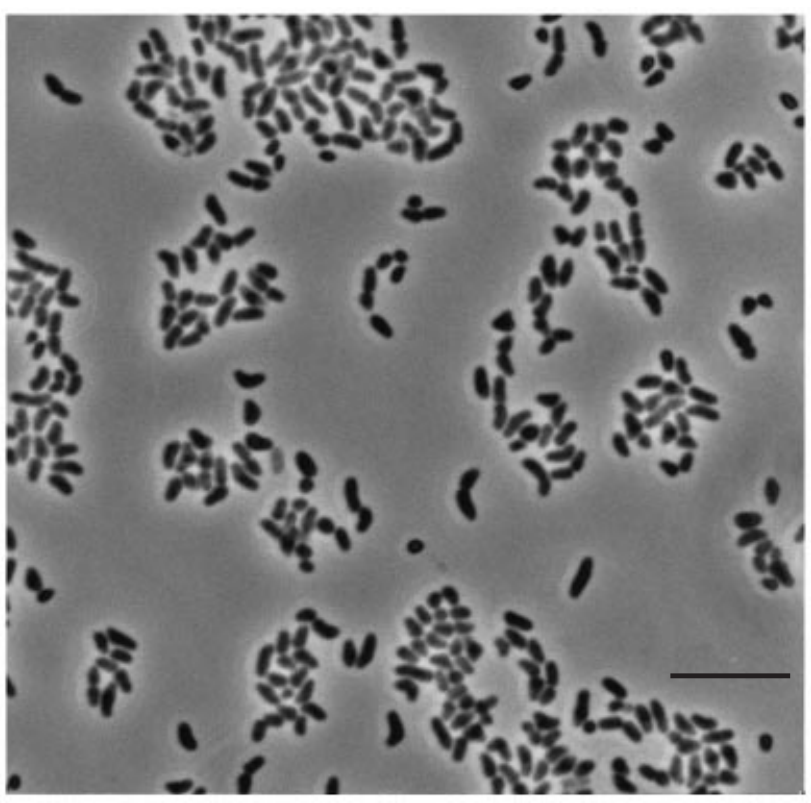

Fig. 2. Micrograph of strain $H K I 0124^{\top}$ grown in liquid $R$ medium for $24 \mathrm{~h}$ at $28^{\circ} \mathrm{C}$. Bar, $10 \mu \mathrm{m}$.

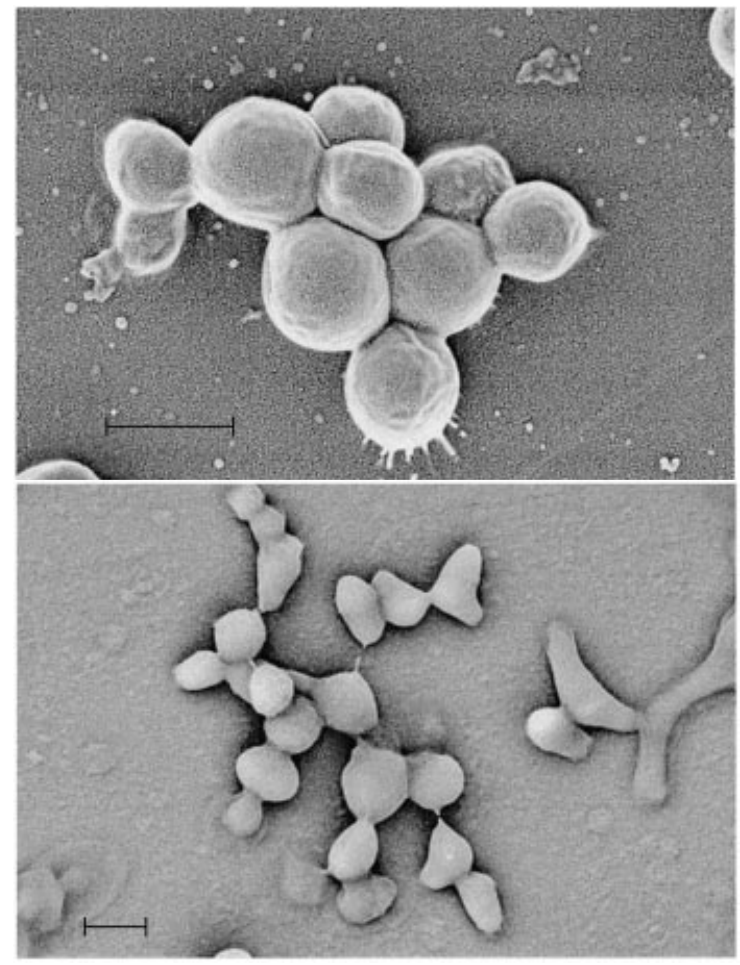

Fig. 3. Scanning electron micrographs of cells from a $3 \mathrm{~d}$ culture of strain $\mathrm{HKI} 0124^{\top}$ grown on R agar at $28^{\circ} \mathrm{C}$. Bars, $1 \mu \mathrm{m}$.

of $0 \cdot 7-1 \cdot 4 \mu \mathrm{m}$. A clearly pronounced rod-coccus growth cycle was not observed. Cells were non-motile and formed no spores (Fig. 2 and Fig. 3). They stained 
Table 1. Differential physiological properties of strains HKI 0124 ${ }^{\top}$ and Ornithinicoccus hortensis HKI 0125

- , Negative; + , positive; w, weakly positive.

\begin{tabular}{|c|c|c|}
\hline Property & HKI $0124^{\mathrm{T}}$ & HKI $0125^{\mathrm{T}}$ \\
\hline \multicolumn{3}{|l|}{ Decomposition of: } \\
\hline Hippurate & - & $\mathrm{w}$ \\
\hline Potato starch & + & - \\
\hline Tween 80 & - & + \\
\hline \multicolumn{3}{|l|}{ Acid produced from: } \\
\hline L-Arabinose & + & - \\
\hline D-Cellobiose & + & - \\
\hline D-Fructose & - & + \\
\hline D-Galactose & + & - \\
\hline D-Glucitol & - & $\mathrm{w}$ \\
\hline Glycerol & - & $\mathrm{w}$ \\
\hline D-Mannitol & - & $\mathrm{w}$ \\
\hline D-Mannose & - & $\mathrm{w}$ \\
\hline D-Ribose & + & - \\
\hline D-Xylose & $\mathrm{w}$ & - \\
\hline \multicolumn{3}{|l|}{ Utilization of: } \\
\hline Aconitate & - & + \\
\hline \multicolumn{3}{|l|}{ Enzyme assay (API ZYM): } \\
\hline Lipase (C14) & - & $\mathrm{w}$ \\
\hline Trypsin & $\mathrm{w}$ & - \\
\hline \multicolumn{3}{|l|}{ Growth at $\left({ }^{\circ} \mathrm{C}\right)$ : } \\
\hline 45 & + & - \\
\hline \multicolumn{3}{|l|}{ Growth in presence of $\mathrm{NaCl}(\mathrm{w} / \mathrm{v})$ : } \\
\hline $10 \%$ & - & $\mathrm{w}$ \\
\hline
\end{tabular}

Gram-positive and were not acid-fast. Colonies were circular, convex, glistening and smooth with an entire margin. Colour changed within the yellow shade from whitish to bright yellow. The colony sizes were in the range $0.3-1 \cdot 2 \mathrm{~mm}$. Two colony types differing in size, colour and growth rate were observed on complex media. While colonies of the pale yellow, opaque type grew rapidly after their transfer on a fresh medium, the growth of the smaller transparent yellow colonies was delayed and somewhat reduced. Considering this heterogeneity in cell and colony morphology the purity of the culture was examined by separate cultivation of each colony type. The sequences of the $16 \mathrm{~S}$ rDNA of both types were determined and compared. The results of the sequence comparisons confirmed the identity of the two cultures, which was equally supported by morphological studies. In subsequent passages of the separated colonies on $\mathrm{R}$ medium, a similar morphological differentiation of the colonies occurred.

After its isolation from soil, strain HKI $0124^{\mathrm{T}}$ exhibited poor growth in the form of a thin confluent lawn on solid complex media. However, growth was improved by serial transfers in laboratory cultivation on complex organic media under aerobic conditions. In a microaerophilic atmosphere, growth was only slightly reduced but did not occur under anaerobic conditions. Optimal temperatures for growth were between 37 and $42{ }^{\circ} \mathrm{C}$. At a temperature of $50{ }^{\circ} \mathrm{C}$, growth was inhibited. Addition of $\mathrm{NaCl}$ to $\mathrm{R}$ medium was tolerated up to a concentration of $6 \%(\mathrm{w} / \mathrm{v})$. At a concentration of $8 \%(\mathrm{w} / \mathrm{v}) \mathrm{NaCl}$ in the agar plates, traces of growth appeared after an incubation time of about $10 \mathrm{~d}$.

Further physiological properties of strain HKI $0124^{\mathrm{T}}$ are listed in Table 1 and compared with the characteristics of the closely related Ornithinicoccus hortensis. The above-mentioned growth behaviour at temperatures in the range $40-50{ }^{\circ} \mathrm{C}$ is an obvious difference between strain HKI $0124^{\mathrm{T}}$ and its phylogenetic neighbour Ornithinicoccus hortensis. While strain HKI $0124^{\mathrm{T}}$ exhibited good growth up to $45^{\circ} \mathrm{C}$, the growth of Ornithinicoccus hortensis was completely inhibited at a temperature of $42{ }^{\circ} \mathrm{C}$.

Strain HKI $0124^{\mathrm{T}}$ was maintained in the form of liquid cultures at a temperature of $-80^{\circ} \mathrm{C}$ and in the vapour phase of liquid nitrogen. The latter is recommended for long-term storage.

\section{Chemotaxonomic characteristics}

The peptidoglycan of strain HKI $0124^{\mathrm{T}}$ contained Orn, Ala, Gly, Glu and Asp in a molar ratio of $0 \cdot 8: 3 \cdot 5: 1 \cdot 6: 1 \cdot 0: 0 \cdot 9$. Dinitrophenylated Asp and only traces of dinitrophenylated Gly and Ala were detected in hydrolysates of cell wall preparations treated with 1fluoro-2,4-dinitrobenzene for labelling of the amino terminus of the interpeptide bridge. Enantiomeric analysis of cell wall amino acids resulted in detection of L-Orn, D-Ala, L-Ala, D-Glu, L-Glu and D-Asp. From these results and from two-dimensional TLC peptide patterns of partial hydrolysates of cell walls (data not shown), it was concluded that strain HKI 0124 contains a peptidoglycan of type A $4 \beta$ (Schleifer \& Kandler, 1972) with an L-Orn $\leftarrow \mathrm{L}-\mathrm{Ala} \leftarrow$ Gly $\leftarrow \mathrm{D}-\mathrm{Asp}$ interpeptide bridge. According to the enantiomeric analysis, both enantiomers of Glu seem to occur in the peptide subunit. The acyl type of the glycan chain of peptidoglycan was acetyl. Glucose, xylose, rhamnose and arabinose were found as whole-cell sugars; the latter three sugars occurred only in traces.

The polar lipid pattern consisted of phosphatidylinositol, phosphatidylglycerol, diphosphatidylglycerol, three unknown glycolipids and three unknown phospholipids. The cellular fatty acids (Table 2) were of the iso and anteiso branched type and were distinctly dominated by the occurrence of 13-methyl tetradecanoic acid and 14-methyl pentadecanoic acid.

The major menaquinone was MK-8( $\left.\mathrm{H}_{4}\right)$. MK- $8\left(\mathrm{H}_{2}\right)$, MK-8 and MK-6 occurred in minor amounts. Mycolic acids were not present. Strain HKI $0124^{\mathrm{T}}$ had a DNA $\mathrm{G}+\mathrm{C}$ content of $70 \mathrm{~mol} \%$.

Based upon chemotaxonomic evidence, the presence of peptidoglycan of type A $4 \beta$ with ornithine and MK- 
Table 2. Cellular fatty acid composition (\%) of strain HKI 0124

The abbreviations for fatty acids are illustrated by the following examples: $\mathrm{C}_{16: 0}$, hexadecanoic acid; $\mathrm{C}_{16: 1}$, hexadecenoic acid; i- $_{15: 0}, 13$-methyl tetradecanoic acid; ai- $\mathrm{C}_{17: 0}, 14-$ methyl hexadecanoic acid.

\begin{tabular}{|lc|}
\hline Fatty acid & Composition (\%) \\
\hline i- $C_{13: 0}$ & $0 \cdot 6$ \\
ai- $C_{13: 0}$ & $0 \cdot 3$ \\
i-C $C_{14: 0}$ & $3 \cdot 4$ \\
$\mathrm{C}_{14: 0}$ & $0 \cdot 2$ \\
$\mathrm{i}-\mathrm{C}_{15: 0}$ & $26 \cdot 0$ \\
$\mathrm{i}-\mathrm{C}_{15: 1}$ & $0 \cdot 8$ \\
ai- $_{15: 0}$ & $10 \cdot 6$ \\
$\mathrm{C}_{15: 0}$ & $1 \cdot 2$ \\
$\mathrm{i}-\mathrm{C}_{16: 0}$ & $27 \cdot 0$ \\
$\mathrm{i}-\mathrm{C}_{16: 1}$ & $2 \cdot 7$ \\
$\mathrm{C}_{16: 0}$ & $1 \cdot 3$ \\
$\mathrm{C}_{16: 1}$ & $0 \cdot 4$ \\
$\mathrm{i}-\mathrm{C}_{17: 0}$ & $4 \cdot 2$ \\
ai-C & \\
i-C $\mathrm{C}_{17: 0}$ & $5 \cdot 2$ \\
ai- $_{17: 1}$ & $9 \cdot 4$ \\
\hline
\end{tabular}

$8\left(\mathrm{H}_{4}\right)$ as major menaquinone, and $16 \mathrm{~S}$ rDNA similarity of $95.2 \%$, strain HKI $0124^{\mathrm{T}}$ is most closely related to Ornithinicoccus hortensis. However, strain HKI $0124^{T}$ is differentiated from Ornithinicoccus hortensis by its unique interpeptide bridge $(\mathrm{L}-\mathrm{Orn} \leftarrow \mathrm{L}-$ Ala $\leftarrow$ Gly $\leftarrow$ D-Asp and L-Orn $\leftarrow \mathrm{Gly}_{(1,2)} \leftarrow \mathrm{D}-\mathrm{Glu}$, respectively). The polar lipid pattern of strain HKI $0124^{\mathrm{T}}$ differs from that of the genus Ornithinicoccus in the absence of phosphatidylserine and the additional occurrence of unidentified glycolipids. The fatty acid profile of strain HKI $0124^{\mathrm{T}}$ is characterized by a considerably higher content of 14-methyl pentadecanoic acid and lower amounts of 12-methyl tetradecanoic acid in comparison to that of Ornithinicoccus hortensis (Table 2). Because of the differences in peptidoglycan structure, polar lipid pattern, fatty acid profile, and physiological (Table 1) and morphological features, as well as in the 16S rDNA sequence, strain HKI $0124^{\mathrm{T}}$ should not be considered a member of the genus Ornithinicoccus. Furthermore, strain HKI $0124^{\mathrm{T}}$ is clearly separated from the other aforementioned genera with ornithine in the peptidoglycan as demonstrated by its position in the phylogenetic tree (Fig. 1) and its differentiating phenotypic characteristics (Table 3). Therefore, it is proposed that the genus Ornithinimicrobium should be established to harbour strain HKI $0124^{\mathrm{T}}$. The type species of the genus Ornithinimicrobium is Ornithinimicrobium humiphilum gen. nov., sp. nov., represented by the type strain HKI $0124^{\mathrm{T}}\left(=\mathrm{DSM} 12362^{\mathrm{T}}=\mathrm{CIP} 106634^{\mathrm{T}}\right)$. As the proposed novel genus and species comprise only a single strain, the given descriptions cannot reflect the phylo- genetic depth and phenotypic variability of the entire taxon.

\section{Description of Ornithinimicrobium gen. nov.}

Ornithinimicrobium (or'ni.thi.ni.mic.ro.bi.um. Gr. n. ornithos bird, ornithine an amino acid named after birds; Gr. adj. micros small; Gr. masc. n. bios life; N.L. neut. n. Ornithinimicrobium a microbe with ornithine).

Cells are irregular short rods and cocci occurring singly, in pairs, short chains or clusters. Cell diameters of the cocci vary from 0.7 to $1.4 \mu \mathrm{m}$. The rods are $1.4-3.2 \times 0.6-1.0 \mu \mathrm{m}$ in size. Gram-positive, not acidfast, non-motile, no formation of spores. Aerobic to microaerophilic. Oxidase-negative, catalase-positive. The peptidoglycan type is A $4 \beta$ with an $\mathrm{L}-\mathrm{Orn} \leftarrow \mathrm{L}-$ Ala $\leftarrow$ Gly $\leftarrow$ D-Asp interpeptide bridge. The acyl type of the glycan chain of peptidoglycan is acetyl. The major menaquinone is MK- $8\left(\mathrm{H}_{4}\right)$. The predominant fatty acids are 13-methyl tetradecanoic and 14-methyl pentadecanoic acid. The polar lipids are phosphatidylinositol, phosphatidylglycerol, diphosphatidylglycerol, three unknown glycolipids and three unknown phospholipids. The $\mathrm{G}+\mathrm{C}$ content of the DNA is $70 \mathrm{~mol} \%$. Phylogenetically, this genus is a member of the suborder Micrococcineae in which it is closely related to members of the family Intrasporangiaceae (Stackebrandt et al., 1997). The type species is Ornithinimicrobium humiphilum.

\section{Description of Ornithinimicrobium humiphilum sp. nov.}

Ornithinimicrobium humiphilum (hu.mi'phil.um. L. adj. humo from soil; Gr. adj. philus liking, preferring; N.L. humiphilum liking soil).

Cells are irregular short rods and cocci occurring singly, in pairs, short chains or clusters. Cell diameters of the cocci vary from 0.7 to $1.4 \mu \mathrm{m}$. The rods are $1.4-3.2 \times 0.6-1.0 \mu \mathrm{m}$. Gram-positive, not acid-fast, non-motile, no formation of spores. Aerobic to microaerophilic. Oxidase-negative, catalase-positive. Colonies are $0.3-1.2 \mathrm{~mm}$ in diameter and vary in colour from whitish to bright yellow. Colony size, colour and growth rate change depending on the composition of the medium. Acids are produced from L-arabinose, Dcellobiose, D-galactose, D-glucose, maltose, D-ribose and starch and in a low amount from dextrin, sucrose, trehalose and D-xylose. No acid production from lactose, D-fructose, D-glucitol, glycerol, inulin, Dmannitol, D-mannose, D-raffinose, L-rhamnose or salicin. Formate is used as sole carbon source. Utilization of malate and succinate is delayed and weakly expressed. Acetate, aconitate, benzoate, citrate and DL-tartrate are not utilized. Nitrate is reduced to nitrite. $\mathrm{H}_{2} \mathrm{~S}$ and catalase are produced, indole and oxidase are not produced. Methyl red and VogesProskauer reactions are negative. Casein, gelatin, hypoxanthine, starch and xanthine are decomposed; 
Table 3. Differential characteristics of strain HKI $0124^{\top}$ and related taxa

Abbreviations: D-Orn, D-ornithine; L-Orn, L-ornithine; meso- $\mathrm{A}_{2} \mathrm{pm}$, meso-diaminopimelic acid; LL-A ${ }_{2} \mathrm{pm}, \mathrm{LL}-\mathrm{diaminopimelic}$ acid; DPG, diphosphatidylglycerol; GL, unknown glycolipid(s); PE, phosphatidylethanolamine; PG, phosphatidylglycerol; PGL, unknown phosphoglycolipid; PI, phosphatidylinositol; PIM, phosphatidylinositolmannoside; PSer, phosphatidylserine; PL, unknown phospholipid(s); A, anteiso methyl branched; I, iso methyl branched; S, straight chain saturated; U, monounsaturated.

\begin{tabular}{|c|c|c|c|c|c|c|c|}
\hline Taxon & Cell morphology & $\begin{array}{c}\text { Wall } \\
\text { diamino } \\
\text { acid }\end{array}$ & $\begin{array}{c}G+C \\
\text { content } \\
(\mathrm{mol} \%)\end{array}$ & $\begin{array}{l}\text { Murein } \\
\text { type }\end{array}$ & $\begin{array}{c}\text { Major } \\
\text { menaquin one }\end{array}$ & $\begin{array}{l}\text { Polar } \\
\text { lipid } \\
\text { type }\end{array}$ & $\begin{array}{l}\text { Fatty } \\
\text { acid } \\
\text { type }\end{array}$ \\
\hline HKI $0124^{\mathrm{T}}$ & $\begin{array}{l}\text { Irregular rods and cocci, } \\
\text { non-motile }\end{array}$ & L-Orn & 70 & $\mathrm{~A} 4 \beta$ & $\mathrm{MK}-8\left(\mathrm{H}_{4}\right)$ & $\begin{array}{l}\text { PI, PG, DPG, } \\
\text { PLs, GLs }\end{array}$ & $\mathrm{S}, \mathrm{A}, \mathrm{I}$ \\
\hline Ornithinicoccus* & Cocci, non-motile & L-Orn & 72 & $\mathrm{~A} 4 \beta$ & $\mathrm{MK}-8\left(\mathrm{H}_{4}\right)$ & $\begin{array}{l}\text { PI, PG, DPG, } \\
\text { PSer, PLs }\end{array}$ & $\mathrm{S}, \mathrm{A}, \mathrm{I}$ \\
\hline Cellulomonas $\dagger$ & $\begin{array}{l}\text { Irregular rods, motile or } \\
\text { non-motile }\end{array}$ & L-Orn & $71-76$ & $\mathrm{~A} 4 \beta$ & $\operatorname{MK}-9\left(\mathrm{H}_{4}\right)$ & DPG, PI, PGL & $\mathrm{S}, \mathrm{A}, \mathrm{I}$ \\
\hline Rarobactert\$ & Rods & L-Orn & $65-66$ & $\mathrm{~A} 4 \beta$ & MK-9 & ND & $\mathrm{S}, \mathrm{A}, \mathrm{I}$ \\
\hline Curtobacterium $\$$ & Irregular rods, motile & D-Orn & $68-75$ & $\mathrm{~B} 2 \beta$ & MK-9 & DPG, PG, GLs & $\mathrm{S}, \mathrm{A}, \mathrm{I}$ \\
\hline Microbacterium $\S \|$ & Irregular rods & $\begin{array}{l}\text { D-Orn, } \\
\text { L-Lys }\end{array}$ & $67-70$ & $\mathrm{~B} 2 \beta, \mathrm{B} 2 \alpha$ & $\begin{array}{l}\text { MK-11, } \\
\text { MK-12, } \\
\text { MK-13, } \\
\text { MK-14 }\end{array}$ & DPG, PG, GL & $\mathrm{S}, \mathrm{A}, \mathrm{I}$ \\
\hline Intrasporangium $\uparrow$ & Hyphae & LL-A ${ }_{2} \mathrm{pm}$ & 68 & $\mathrm{~A} 3 \gamma$ & MK-8 & $\begin{array}{l}\text { PI, PIM, PG, } \\
\text { DPG }\end{array}$ & $\mathrm{S}, \mathrm{A}, \mathrm{I}$ \\
\hline Terrabacter\# & Rod-coccus cycle & LL-A $\mathrm{A}_{2} \mathrm{pm}$ & $70-73$ & $\mathrm{~A} 3 \gamma$ & $\mathrm{MK}-8\left(\mathrm{H}_{4}\right)$ & $\begin{array}{l}\text { DPG, PI, PE, } \\
\text { PL }\end{array}$ & $\mathrm{S}, \mathrm{A}, \mathrm{I}$ \\
\hline Terracoccus ${ }^{* *}$ & $\begin{array}{l}\text { Cocci in packets, } \\
\text { non-motile }\end{array}$ & $\mathrm{LL}-\mathrm{A}_{2} \mathrm{pm}$ & 73 & $\mathrm{~A} 3 \gamma$ & $\mathrm{MK}-8\left(\mathrm{H}_{4}\right)$ & $\begin{array}{l}\text { PE, PI, PG, } \\
\text { DPG }\end{array}$ & $\mathrm{S}, \mathrm{A}, \mathrm{I}$ \\
\hline Janibacter\# & $\begin{array}{l}\text { Coccoid to rod-shaped, } \\
\text { non-motile }\end{array}$ & meso- $\mathrm{A}_{2} \mathrm{pm}$ & 70 & $\mathrm{~A} 1 \gamma$ & $\mathrm{MK}-8\left(\mathrm{H}_{4}\right)$ & DPG, PG, PI & $\mathrm{S}, \mathrm{I}, \mathrm{U}$ \\
\hline
\end{tabular}

* Data from Groth et al. (1999).

$\dagger$ Data from Stackebrandt et al. (1995).

† Data from Yokota et al. (1993).

$\S$ Data from Goto-Yamamoto et al. (1993).

| Data from Takeuchi \& Hatano (1998).

- Data from Schumann et al. (1997).

\# Data from Martin et al. (1997).

** Data from Prauser et al. (1997).

adenine, aesculin, hippurate, Tween 80 , tyrosine and urea are not. Addition of $\mathrm{NaCl}$ to $\mathrm{R}$ medium is well tolerated up to a concentration of $6 \%(\mathrm{w} / \mathrm{v})$. Good growth occurs between 37 and $42{ }^{\circ} \mathrm{C}$; no growth at $50{ }^{\circ} \mathrm{C}$. Cells are susceptible to ampicillin $(10 \mu \mathrm{g})$, chloramphenicol $(30 \mu \mathrm{g})$, ciprofloxacin $(5 \mu \mathrm{g})$, erythromycin $(15 \mu \mathrm{g})$, gentamicin $(10 \mu \mathrm{g})$, kanamycin $(30 \mu \mathrm{g})$, lincomycin $(2 \mu \mathrm{g})$, neomycin $(30 \mu \mathrm{g})$, nitrofuran $(300 \mu \mathrm{g})$, oxytetracycline $(30 \mu \mathrm{g})$, penicillin $\mathrm{G}(2 \mathrm{IU})$, polymyxin B (300 IU), rifampicin $(2 \mu \mathrm{g})$ and streptomycin $(10 \mu \mathrm{g})$. No susceptibility to oxacillin $(5 \mu \mathrm{g})$ or sulfonamide $(300 \mu \mathrm{g})$. Tested by the API ZYM enzyme assay, strain HKI $0124^{\mathrm{T}}$ is positive for alkaline phosphatase, esterase (C4), esterase lipase (C8), leucine arylamidase, valine arylamidase, cystine arylamidase, acid phosphatase, naphthol-AS-BI-phosphohydrolase and $\alpha$-glucosidase and negative for lipase $(\mathrm{C} 14), \alpha$ galactosidase, $\beta$-galactosidase, $\beta$-glucuronidase, $\beta$-glu- cosidase, $N$-acetyl- $\beta$-glucosamidase, $\alpha$-mannosidase and $\alpha$-fucosidase. The enzyme assay showed a weak reaction for trypsin and chymotrypsin. The peptidoglycan is of the A4 $\beta$ type with an $\mathrm{L}-\mathrm{Orn} \leftarrow \mathrm{L}-$ Ala $\leftarrow$ Gly $\leftarrow$ D-Asp interpeptide bridge. The acyl type of the glycan chain of peptidoglycan is acetyl. The fatty acids are of the iso and anteiso branched type with predominant amounts of 13-methyl tetradecanoic acid and 14-methyl pentadecanoic acid. The major menaquinone is $\mathrm{MK}-8\left(\mathrm{H}_{4}\right)$. The polar lipids are phosphatidylinositol, phosphatidylglycerol, diphosphatidylglycerol, three unknown glycolipids and three unknown phospholipids. Glucose is the dominating whole cell sugar; arabinose, rhamnose and xylose are found in traces. The $\mathrm{G}+\mathrm{C}$ content of the DNA is $70 \mathrm{~mol} \%$. Mycolic acids are absent. The habitat is soil. The type strain is HKI $0124^{\mathrm{T}}$ (= DSM $12362^{\mathrm{T}}=$ CIP $106634^{\mathrm{T}}$ ). 


\section{ACKNOWLEDGEMENTS}

The authors thank Ina Kramer, Carmen Schult and Christiane Weigel for excellent technical assistance.

\section{REFERENCES}

Brosius, J., Palmer, M. L., Kennedy, P. J. \& Noller, H. F. (1978). Complete nucleotide sequence of the 16S ribosomal RNA gene from Escherichia coli. Proc Natl Acad Sci US A 75, 4801-4805.

Collins, M. D. \& Jones, D. (1980). Lipids in the classification and identification of coryneform bacteria containing peptidoglycans based on 2,4-diaminobutyric acid. J Appl Bacteriol 48, 459-470.

Collins, M. D., Pirouz, T., Goodfellow, M. \& Minnikin, D. E. (1977). Distribution of menaquinones in actinomycetes and corynebacteria. J Gen Microbiol 100, 221-230.

De Soete, G. (1983). A least square algorithm for fitting additive trees to proximity data. Psychometrika 48, 621-626.

Felsenstein, J. (1993). PHYLIP (phylogenetic inference package) version 3.5.1. Department of Genetics, University of Washington, Seattle, USA.

Frank, H., Rettenmeier, A., Weicker, H., Nicholson, G. J. \& Bayer, E. (1980). A new gas chromatographic method for determination of amino acid levels in human serum. Clin Chim Acta 105, 201-211.

Goto-Yamamoto, N., Sato, S.-I., Miki, H., Park, Y. K. \& Tadenuma, M. (1993). Taxonomic studies on yeast-lysing bacteria, and a new species Rarobacter incanus. J Gen Appl Microbiol 39, 261-272.

Groth, I., Schumann, P., Weiss, N., Martin, K. \& Rainey, F. A. (1996). Agrococcus jenensis gen. nov., sp. nov., a new genus of actinomycetes with diaminobutyric acid in the cell wall. Int $J$ Syst Bacteriol 46, 234-239.

Groth, I., Schumann, P., Rainey, F. A., Martin, K., Schuetze, B. \& Augsten, K. (1997). Demetria terragena gen. nov., sp. nov., a new genus of actinomycetes isolated from compost soil. Int $J$ Syst Bacteriol 47, 1129-1133.

Groth, I., Schumann, P., Martin, K., Schuetze, B., Augsten, K., Kramer, I. \& Stackebrandt, E. (1999). Ornithinicoccus hortensis gen. nov., sp. nov., a soil actinomycete which contains Lornithine. Int J Syst Bacteriol 49, 1717-1724.

Jukes, T. H. \& Cantor, C. R. (1969). Evolution of protein molecules. In Mammalian Protein Metabolism, vol. 3, pp. 21-132. Edited by H. N. Munro. New York: Academic Press.

MacKenzie, S. L. (1987). Gas chromatographic analysis of amino acids as the $N$-heptafluorobutyryl isobutyl esters. $J$ Assoc Off Anal Chem 70, 151-160.

Maidak, B. L., Larsen, N., McCaughey, M. J., Overbeek, R., Olsen, G. J. \& Woese, C. R. (1997). The Ribosomal Database Project. Nucleic Acids Res 25, 109-111.

Martin, K., Schumann, P., Rainey, F. A., Schuetze, B. \& Groth, I. (1997). Janibacter limosus gen. nov., sp. nov., a new actino- mycete with meso-diaminopimelic acid in the cell wall. Int $J$ Syst Bacteriol 47, 529-534.

Minnikin, D. E., Alshamaony, L. \& Goodfellow, M. (1975). Differentiation of Mycobacterium, Nocardia, and related taxa by thin-layer chromatographic analysis of whole-organism methanolysates. J Gen Microbiol 88, 200-204.

Minnikin, D. E., Collins, M. D. \& Goodfellow, M. (1979). Fatty acid and polar lipid composition in the classification of Cellulomonas, Oerskovia and related taxa. J Appl Bacteriol 47, 87-95.

Prauser, H., Schumann, P., Rainey, F. A., Kroppenstedt, R. M. \& Stackebrandt, E. (1997). Terracoccus luteus gen. nov., sp. nov., an LL-diaminopimelic acid-containing coccoid actinomycete from soil. Int J Syst Bacteriol 47, 1218-1224.

Rainey, F. A., Ward-Rainey, N., Kroppenstedt, R. M. \& Stackebrandt, E. (1996). The genus Nocardiopsis represents a phylogenetically coherent taxon and a distinct actinomycete lineage: proposal of Nocardiopsaceae fam. nov. Int J Syst Bacteriol 46, 1088-1092.

Schleifer, K. H. (1985). Analysis of the chemical composition and primary structure of murein. Methods Microbiol 18, 123-156.

Schleifer, K. H. \& Kandler, O. (1972). Peptidoglycan types of bacterial cell walls and their taxonomic implications. Bacteriol Rev 36, 407-477.

Schumann, P., Prauser, H., Rainey, F. A., Stackebrandt, E. \& Hirsch, P. (1997). Friedmanniella antarctica gen. nov., sp. nov., an LL-diaminopimelic acid-containing actinomycete from Antarctic sandstone. Int $J$ Syst Bacteriol 47, 278-283.

Stackebrandt, E., Koch, C., Gvozdiak, O. \& Schumann, P. (1995). Taxonomic dissection of the genus Micrococcus: Kocuria gen. nov., Nesterenkonia gen. nov., Kytococcus gen. nov., and Micrococcus Cohn 1872 gen. emend. Int J Syst Bacteriol 45, 682-692.

Stackebrandt, E., Rainey, F. A. \& Ward-Rainey, N.-L. (1997). Proposal for a new hierarchic classification system, Actinobacteria classis nov. Int $J$ Syst Bacteriol 47, 479-491.

Stead, D. E., Sellwood, J. E., Wilson, J. \& Viney, I. (1992). Evaluation of a commercial microbial identification system based on fatty acid profiles for rapid, accurate identification of plant pathogenic bacteria. J Appl Bacteriol 72, 315-321.

Takeuchi, M. \& Hatano, K. (1998). Union of the genera Microbacterium Orla-Jensen and Aureobacterium Collins et al. in a redefined genus Microbacterium. Int J Syst Bacteriol 48, 739-747.

Uchida, K. \& Aida, K. (1984). An improved method for the glycolate test for simple identification of the acyl type of bacterial cell walls. J Gen Appl Microbiol 30, 131-134.

Yokota, A., Takeuchi, M., Sakane, T. \& Weiss, N. (1993). Proposal of six new species of the genus Aureobacterium and transfer of Flavobacterium esteraromaticum Omelianski to the genus Aureobacterium as Aureobacterium esteraromaticum comb. nov. Int J Syst Bacteriol 43, 555-564. 